\title{
NATURAL RECREATION POTENTIAL OF THE WEST KAZAKHSTAN REGION OF THE REPUBLIC OF KAZAKHSTAN
}

\author{
Bibigul CHASHINA \\ L.N. Gumilyov Eurasian National University, Faculty of Natural Sciences, Satpayev Str., 2, \\ 010008 Nur-Sultan, Republic of Kazakhstan, e-mail: bikuwa81 @ mail.ru \\ Nurgul RAMAZANOVA \\ L.N. Gumilyov Eurasian National University, Faculty of Natural Sciences, Satpayev Str., 2, \\ 010008 Nur-Sultan, Republic of Kazakhstan, e-mail: nurgulram@gmail.ru
}

\section{Emin ATASOY}

Bursa Uludag University, 6059, Gorukle, Bursa, Turkye, e-mail: eatasoy@uludag.edu.tr

\section{Zharas BERDENOV*}

L.N. Gumilyov Eurasian National University, Faculty of Natural Sciences, Satpayev Str., 2, 010008 Nur-Sultan, Republic of Kazakhstan, e-mail: berdenov-z@mail.ru

\section{Dorina Camelia ILIES}

University of Oradea, Faculty of Geography, Tourism and Sport, Department of Geography, Tourism and Territorial Planning, Oradea, Romania, e-mail: iliesdorina@yahoo.com

Citation: Chashina, B., Ramazanova, N., Atasoy, E., Berdenov, Zh., \& Ilieș, D.C. (2020). NATURAL RECREATION POTENTIAL OF THE WEST KAZAKHSTAN REGION OF THE REPUBLIC OF KAZAKHSTAN. GeoJournal of Tourism and Geosites, 32(4), 1355-1361. https://doi.org/10.30892/gtg.32424-580

\begin{abstract}
This article is an attempt to assess the natural and recreational potential of the West Kazakhstan region. This technique consists of different stages: assessment of the territory concerning the recreational potential, according to the physical and geographical conditions; determination of administrative districts (units) within each of the recreational development zones; inventory of specially protected natural areas.The main criterion for the quantitative assessment was the presence of specially protected natural are as, their number and occupied area. In the course of the study, the analysis of natural and recreational resources was carried out by zones of potential recreational development, and the highest priority zones of recreational development were identified.
\end{abstract}

Key words: quantitative assessment of natural and recreational potential specially protected natural areas, the West Kazakhstan region, natural and recreational zones, natural and recreational resources

\section{INTRODUCTION}

As world practice shows, one of the most effective and promising ways to preserve the pristine uniqueness of natural landscapes and geosystems is rational tourism and recreation nature management. In order to optimize the use of natural and recreational resources and with account taken of the anthropogenic load of recreation and tourism, an assessment of the natural and recreational potential of the territory is carried out. Assessment issues were dealt with in different periods by Russian (Preobrazhensky, 1975; Mironenko and Tverdokhlebov, 1981; Kuskov, 2005) and Kazakhstani scientists (Erdavletov, 2000; Berdenov, 2016), and by foreign authors as well (Mitchell, 1979; Page, 2011).

Due to the physical and geographical location, the peculiarities of the geological and geomorphological structure and landscape diversity, the West Kazakhstan region has sufficient natural resource potential for the development of recreation and such types of tourism as ecotourism, "green" (agritourism), water tourism and other types. The works of the following scientists are devoted to the study of the landscape biodiversity of the geosystems of the West Kazakhstan region: Chibilev (1987, 2008); Petrenko and Fartushina (2001); Darbayeva (2020); Ramazanov (1998); Ilieș and Grama, 2010; Ilieș et al., (2017); Dzhanaleyeva and Ramazanova (2012, 2019), Azhayev et al., 2020; Suleimenov et al., 2020. Natural and recreational resources as a basis for the development of tourism and recreation are considered in the works of Akhmedenov and Svanbayeva (2016), Nuruly and Aktymbayeva (2017), Deac et al., 2019; Lincu et al., 2018 and others.

\section{MATERIALS AND METHODS}

The methodology of assessing the natural and recreational potential of the region allows us to identify the most valuable territories of the region from the recreational point of view. For this purpose, the entire territory is divided into several districts (zones), characterized by a certain number of territorial and recreational features (Wendt, 2020; Beketova, 2019; Ilieș et al., 2018; 2020).

As a methodological instrument for assessing the tourist and recreational potential of the study area, the methodology for calculating the estimated indicator of the natural and recreational indicator of the territory, developed by Yegorova and Motrich (2010) was selected. This technique consists of several stages:

$1^{\text {st }}$ stage of the assessment - the differentiation of the territory into zones of potential recreational development according to the peculiarities of physical and geographical conditions;

$2^{\text {nd }}$ stage - determination of administrative districts (units) within each of the recreational development zones;

$3^{\text {rd }}$ stage - determination of the list of specially protected natural areas; 
$4^{\text {th }}$ stage - a quantitative assessment of the natural and recreational potential (Yegorova, 2010);

$5^{\text {th }}$ stage - counting and summing up for each of the recreational areas.

\section{STUDY OBJECT}

The object of the study is the West Kazakhstan region with an area of $151.339 \mathrm{~km}^{2}$, which is located in the north-west of the country and borders the Russian Federation in the north. The region was formed at the junction of such large physical and geographical countries and provinces as the Obshchy Syrt (southern part) and the Caspian lowland (northern part), which are the constituent provinces of the East European Plain, and the Podural Plateau (Figure 1).

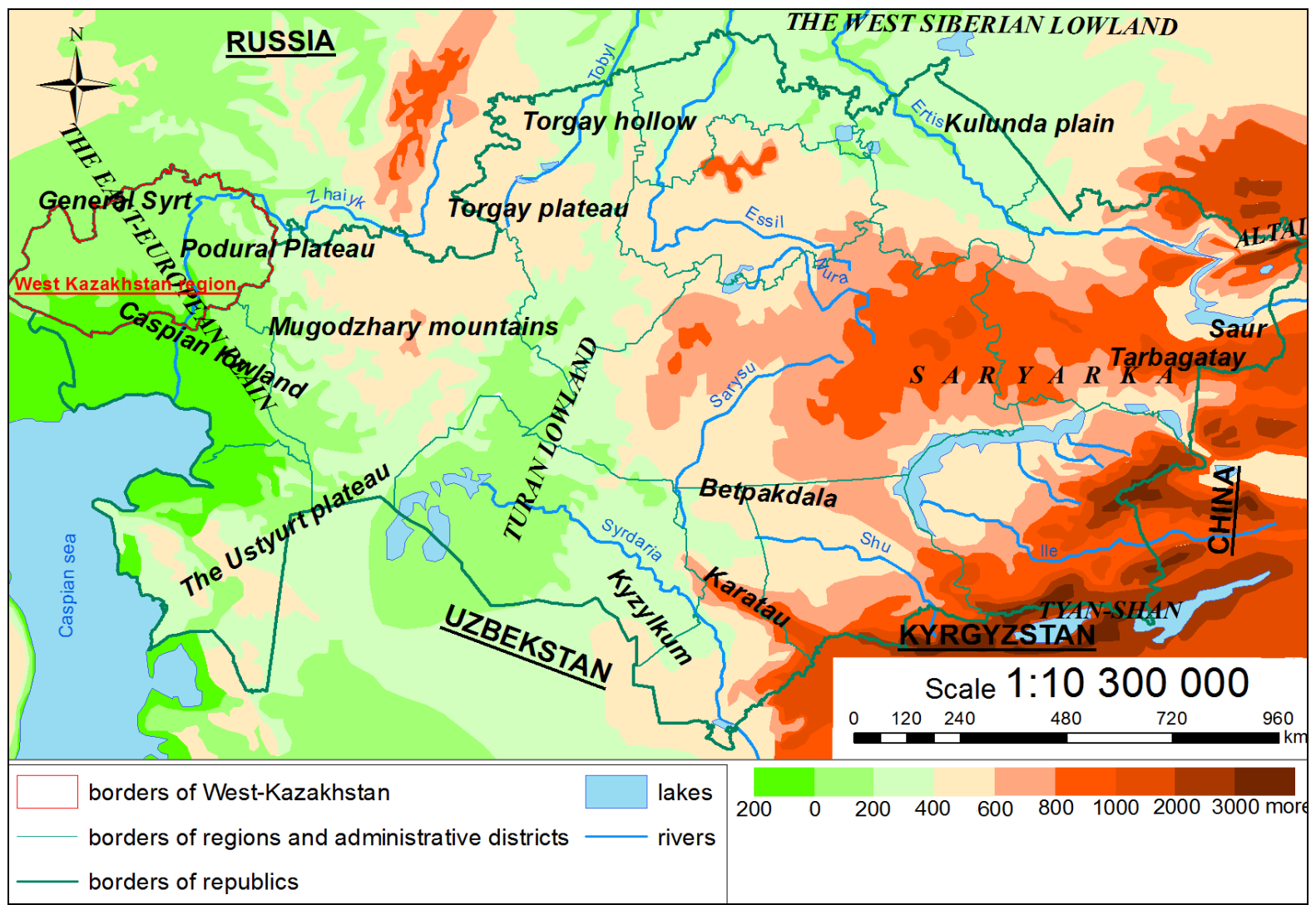

Figure 1. Physical map of Kazakhstan (Source: Compiled by the authors, based on SRTM images from 2018)

In terms of geosystem-basin relations, the main part of the territory of the West Kazakhstan region is occupied by the basin of the middle course of the Zhaiyk River (Ural), which divides the region into approximately equal parts. The length of the river is $781 \mathrm{~km}$ within the region, $1084 \mathrm{~km}$ within the country, and the total length is $2428 \mathrm{~km}$ (Chibilev, 2008; Kabiyev, 2018). The Zhaiyk River is not only the largest waterway in the region, but also one of the main landscape-forming factors, in the basin of which unique natural complexes have been formed, and water areas are the only spawning ground for sturgeon fish in Eurasia (Chibilev, 1987).

The entire floodplain of the Urals is a unique ecological system. A large number of monuments of the South Ural and Caspian nature are concentrated here. The flora and fauna of the Zhaiyk River basin is distinctive and inimitable - there are many relics, endemics, rare and endangered species (Chibilev, 2008; Darbayeva, 2020).

\section{RESULTS DISCUSSIONS}

In accordance with the above stated methodology, the study area should be divided into zones with characteristic natural and recreational resources. During the implementation of the $1^{\text {st }}$ stage of the study, the geomorphological structure of the territory served as the main principle of division into zones, since the relief, being the result of geological-tectonic processes, serves as a frame of landscape diversity. At the same time, the relief itself determines its further development, influences the formations of natural-climatic, hydrographic conditions, as well as the characteristics of the soil and vegetation cover.

In general, the surface of the region decreases in the direction from northeast to southwest and is rather clearly divided in to five large geomorphological regions (Doskach, 1954): the western part of the Podural Plateau, the southern part of the Obshchy Syrt upland, the Predsyrtovy ledge, the northern part of the Caspian lowland and valley of the middle course of the Zhaiyk (Ural) River in figure 2. In accordance with this, the study area is subdivided into 5 recreational zones.

Zone I - the southern part of the Obshchy Syrt in the southeast of the East European Plain, which is characterized by flat, almost undivided watersheds with an absolute height of 200-250 m and flat-topped ridges (Vilesov et al., 2009).

Zone II - the western part of the Podural Plateau (Khobdin province of the East European Plain), represented by a tectonic-denudation ledge. The main types of relief are pre-Quaternary structural plains formed on Cretaceous and Paleogene deposits by processes of salt tectonics and denudation (Vilesov et al., 2009).

Zone III - an intermediate position between the Obshchy Syrt and the Podural Plateau, on the one hand, and the Caspian lowland, on the other, within absolute heights of 50-100 m. The Predsyrtovy ledge is an inclined deluvial-proluvial accumulative plain, which is divided everywhere by valleys of small rivers, oriented almost strictly from north to south (Amelchenko and Galimov, 2006).

Zone IV - the northern part of the Caspian lowland, located below $50 \mathrm{~m}$ and gradually decreasing to the south to $0 \mathrm{~m}$, and in some places 
minus $10 \mathrm{~m}$. Numerous shallow depressions of various origins (swales, limans, sors, depressions, suffusion saucers) and rises (inselbergs, hillocks, ridges) are typical. There are sandy massifs (Amelchenko and Galimov, 2006).

Zone $\mathbf{V}$ - the valley of the Zhaiyk (Ural) River. The second largest (after the Volga River), which flows into the Caspian, flows in the sublatitudinal direction in the north, and in the meridional direction to the south of Uralsk. The river flows between the Obshchy Syrt and the Podural Plateau along the Predsyrtovy ledge and enters the Caspian lowland (Amelchenko and Galimov, 2006).

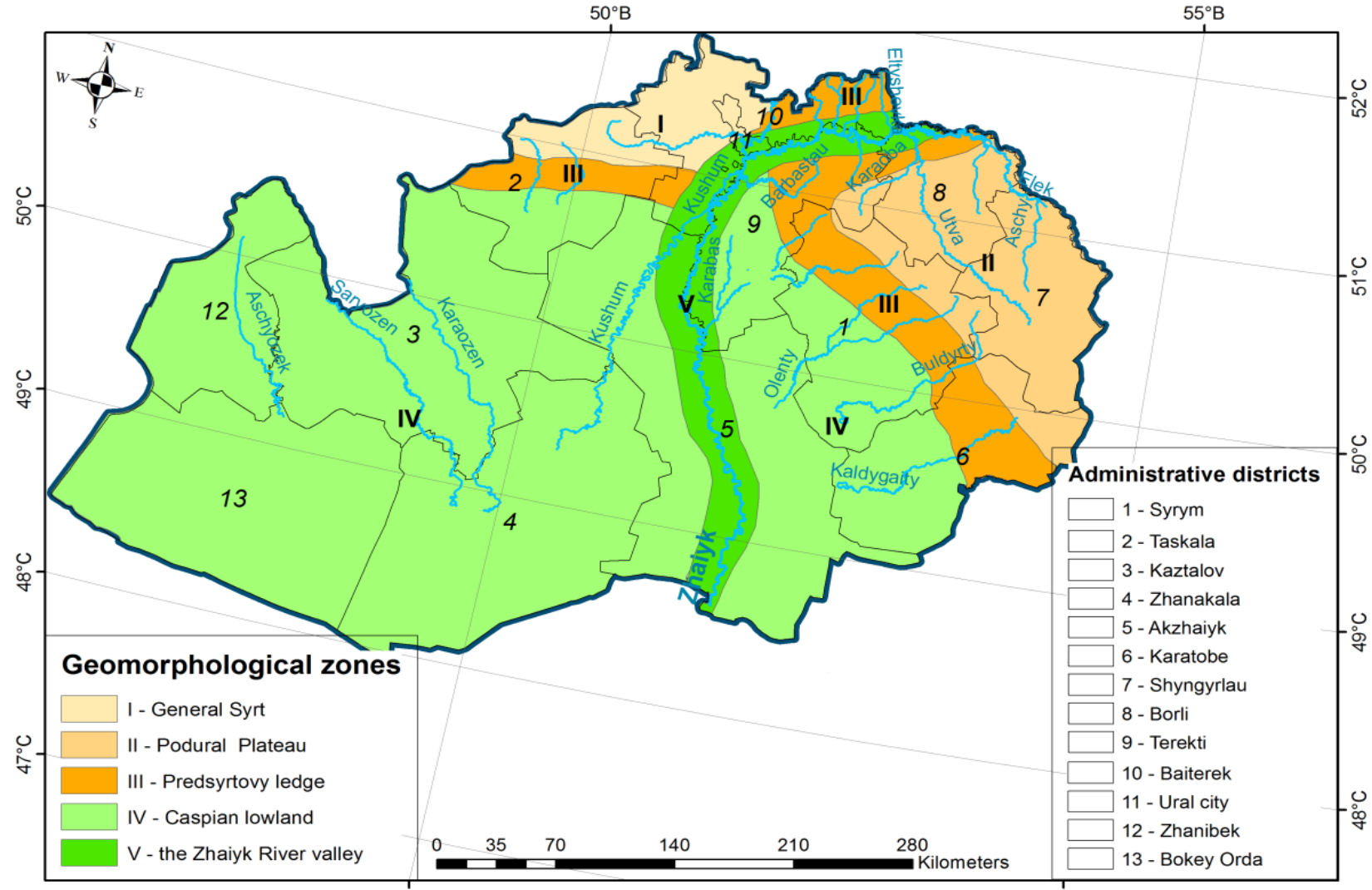

Figure 2. Differentiation of the territory of the West Kazakhstan region by zones

of potential recreational development (compiled by the author according to the method Doskach, 1954)

On the territory of the West Kazakhstan region there are a large number of natural and recreational facilities that have a tourist and recreational potential. The need to include these objects in the list of specially protected areas is reflected in the works of many researchers of the region (Petrenko, 2001; Chibilev, 2006; Akhmedenov, 2015, 2020; Ramazanov, 2003, 2009 and other scientists). In the course of studying the scientific works of researchers, the main natural and recreational resources were identified (Table 1).

Table 1. Natural and recreational resources of the West Kazakhstan region (compiled by the author based on his own research and data Akhmedenov, 2020)

\begin{tabular}{|c|c|c|c|}
\hline Zone & Natural and recreational resources & Specially protected natural areas & Recreational activity types \\
\hline $\begin{array}{l}\text { Obshchy Syrt } \\
\left(6232,17 \mathrm{~km}^{2)}\right.\end{array}$ & $\begin{array}{l}\text { Floodplain landscapes of the Derkul River, outlier } \\
\text { forest of Yemenzhara, Kaiynzhara, aspen forests, a } \\
\text { standard section of wheatgrass estuaries }\end{array}$ & $\begin{array}{c}\text { Natural monument Mount Bolshaya } \\
\text { Ichka }\end{array}$ & $\begin{array}{l}\text { Ecotourism, seasonal sport hunting, } \\
\text { local fishing }\end{array}$ \\
\hline $\begin{array}{l}\text { Podural Plateau } \\
\left(16159.5 \mathrm{~km}^{2}\right)\end{array}$ & $\begin{array}{c}\text { Floodplain of the Bakanas and Kaldygayty Rivers, } \\
\text { Egindikol and Shoshkaly lakes, Almaztau and Kosoba } \\
\text { mountains, Karatal woodland, Kandykty, Karaagash, } \\
\text { Dadem-agash spring }\end{array}$ & $\begin{array}{c}\text { Akkum landscape reserve, } \\
\text { Mirgorodskiy botanical and zoological } \\
\text { natural monument }\end{array}$ & $\begin{array}{l}\text { Ecotourism, seasonal sport hunting, } \\
\text { local fishing }\end{array}$ \\
\hline $\begin{array}{l}\text { Caspian lowland } \\
\left(103496.4 \mathrm{~km}^{2}\right)\end{array}$ & $\begin{array}{c}\text { Steppe rivers and lakes, balneological resources of } \\
\text { lakes (Shalkar, Khakisor, Aralsor, Batpak, Alzhansor), } \\
\text { Naryn sands, historical and archaeological landscapes } \\
\text { (Saka kurgans Akadyr, Koltaban, Akoba), Santas } \\
\text { town, Sasai town, Naryn sands, Kyzylshagyl gorge, } \\
\text { Meshet-Kum }\end{array}$ & $\begin{array}{l}\text { Zhaltyrkol State Nature Reserve, } \\
\text { Shalkar Biohydrological Reserve, } \\
\text { Urdinsky Geobotanical Reserve }\end{array}$ & $\begin{array}{l}\text { Fishing, water, summer health- } \\
\text { improving, medical tourism (mud } \\
\text { therapy, kumis therapy), sport hunting, } \\
\text { ecotourism, agritourism, educational } \\
\text { and scientific tourism }\end{array}$ \\
\hline
\end{tabular}

The $2^{\text {nd }}$ stage of the study. The list of administrative districts of the West Kazakhstan region that are part of a particular potential recreational zone is presented in table 2.

The $3^{\text {rd }}$ stage of the study - a list specially protected natural areas by category (Table 3 ). 
Depending on the presence and nature of protection of natural complexes, as well as the status of specially protected areas, 3 main categories are distinguished:

- reserves of republican significance;

- reserves of regional significance;

- natural monuments.

There are 11 specially protected natural areas in the West Kazakhstan region, including 3 - reserves of republican significance (Resolution of the Government of the Republic of Kazakhstan, dated September 26, 2017 No. 593 "On approval of the list of specially protected natural areas of republican significance"), 3 - reserves of local significance, 5 - natural monuments.

Table 2. Placement of the administrative districts of the West Kazakhstan region on the territory of the designated potential natural and recreational zones

\begin{tabular}{|c|c|c|c|}
\hline Zone & Number on the map (Figure 2) & Administrative unit & Number on the map \\
\hline \multirow{2}{*}{ Obshchy Syrt } & \multirow{2}{*}{ I } & Baiterek (Zelenovsky) District & 10 \\
\hline & & Taskala District & 2 \\
\hline \multirow{5}{*}{ Podural Plateau } & \multirow{5}{*}{ II } & Shyngyrlau District & 7 \\
\hline & & Borli District & 8 \\
\hline & & Terekti District & 9 \\
\hline & & Syrym District & 1 \\
\hline & & Karatobe District & 6 \\
\hline \multirow{5}{*}{ Predsyrtovy ledge } & \multirow{5}{*}{ III } & Taskala District & 2 \\
\hline & & Baiterek District & 10 \\
\hline & & Terekti District & 9 \\
\hline & & Syrym District & 1 \\
\hline & & Karatobe District & 6 \\
\hline \multirow{9}{*}{ Caspian lowland } & \multirow{9}{*}{ IV } & Syrym District & 1 \\
\hline & & Taskala District & 2 \\
\hline & & Kaztalov District & 3 \\
\hline & & Zhanakala District & 4 \\
\hline & & Akzhaiyk District & 5 \\
\hline & & Karatobe District & 6 \\
\hline & & Terekti District & 9 \\
\hline & & Zhanibek District & 12 \\
\hline & & Bokey Orda District & 13 \\
\hline \multirow{5}{*}{ The Zhaiyk River valley } & \multirow{5}{*}{ V } & Baiterek (Zelenovsky) District & 10 \\
\hline & & Territory subordinated to the city of Uralsk & 11 \\
\hline & & Terekti District & 9 \\
\hline & & Akzhaiyk District & 5 \\
\hline & & Borli District & 8 \\
\hline
\end{tabular}

If the reserve is located on the territory of three districts, "1/3" is indicated next to the name of the reserve. This means that this reserve belongs to three administrative districts (Yegorova, 2010).

$4^{\text {th }}$ stage. For each of the three categories of specially protected objects, the number and conditional area is calculated in absolute and relative terms (Table 4). Then they are summed for each recreational area in the "Total" lines.

Table 3. Qualitative assessment of the natural and recreational potential of the West Kazakhstan region

\begin{tabular}{|c|c|c|c|c|}
\hline \multirow{2}{*}{ Zone } & \multirow{2}{*}{ Administrative district } & \multicolumn{3}{|c|}{ Name of specially protected natural area } \\
\hline & & Reserve of Republican significance & Reserve of regional significance & Natural monument \\
\hline Obshchy Syrt & Taskala & & & Mount Bolshaya Ichka - 175 ha \\
\hline \multirow{2}{*}{$\begin{array}{l}\text { Podural } \\
\text { Plateau }\end{array}$} & Shyngyrlau & & Akkum reserve -9000 ha $-1 / 2$ & \\
\hline & Karatobe & & Akkum reserve $-9000 \mathrm{ha}-1 / 2$ & \\
\hline \multirow{3}{*}{$\begin{array}{l}\text { Caspian } \\
\text { lowland }\end{array}$} & Zhanakala & Zhaltyrkol Reserve - 19000 ha & & \\
\hline & Terekti & & Shalkar Reserve- 60000 ha & \\
\hline & Bokey Orda & & Urdinsky Reserve -16400 ha & \\
\hline \multirow{5}{*}{$\begin{array}{l}\text { The Zhaiyk } \\
\text { River valley }\end{array}$} & Baiterek & $\begin{array}{l}\text { Kirsanovsky Reserve }-61000 \text { ha }-1 / 3 \\
\text { Budarinsky }-80000 \text { ha }-1 / 2\end{array}$ & & \begin{tabular}{|l|} 
Sadovskoye Lake -150 ha \\
"Selektsionnyi" -36 ha $-1 / 2$
\end{tabular} \\
\hline & $\begin{array}{l}\text { Territory subordinated } \\
\text { to the city of Uralsk }\end{array}$ & & & "Selektsionnyi" - 36 ha $-1 / 2$ \\
\hline & Terekti & Kirsanovsky Reserve -61000 ha $-1 / 3$ & & "Dubravy" - 6 ha \\
\hline & Akzhaiyk & Budarinsky Reserve -80000 ha $-1 / 2$ & & \\
\hline & Borli & Budarinsky Reserve -61000 ha $-1 / 3$ & & \\
\hline
\end{tabular}

$\mathbf{5}^{\text {th }}$ stage - the results of the calculation are summarized in a separate table, in which the indicators "Quantity" and "Conditional area" of objects for each category are indicated in percentage (Table 5). Then the indicator "Cumulative rating" is determined by multiplying the percentage indicators "Quantity" and "Conditional area" for subsequent ranking. The higher the value of the "Cumulative rating" indicator, the higher the cumulative recreational potential is.

Further, the zones are ranked according to the "Cumulative rating" indicator in each category of specially protected objects.

In order to identify the most promising areas for the development of tourist and recreational activities, each zone is assigned its own cumulative rank for each category of objects: "Cumulative rank 1" - for reserves of republican significance, "Cumulative rank 2" - for reserves of regional significance, "Cumulative rank $3 "$ - on natural monuments.

The total score of all three cumulative ranks is then calculated for each recreational zone. Based on the obtained values, the level of the recreational potential is determined. 
In this methodology, it is proposed to consider 4 levels of recreational potential: high, medium, low and insignificant. As a result, the level of recreational potential is determined for each of the recreational zones differentiated in the region. The assessment of the recreational potential in this methodology is based on taking into account the recreational factors of the area under consideration - those factors that objectively demonstrate the recreational value of the area: the number of specially protected areas located on the territory of the area under consideration and the conditional area occupied by them.

The highest level is obtained in those recreational areas in which recreational factors (such as the quantity and area of 3 categories of protected objects) take on the highest values.

Table 4. Quantitative characteristics of the recreational potential of the West Kazakhstan region in accordance with the regional differentiation of the territory

\begin{tabular}{|c|c|c|c|c|c|c|c|c|c|c|c|}
\hline \multirow{3}{*}{ Recreational zones } & \multirow{3}{*}{ Administrative Districts } & \multicolumn{4}{|c|}{ Reserves of republican significance } & \multicolumn{4}{|c|}{ Reserves of local significance } & \multirow{2}{*}{\multicolumn{2}{|c|}{$\begin{array}{c}\text { Natural } \\
\text { monuments }\end{array}$}} \\
\hline & & \multicolumn{2}{|c|}{ Quantity of objects } & \multicolumn{2}{|c|}{ Conditional area } & \multicolumn{2}{|c|}{ Quantity of objects } & \multicolumn{2}{|c|}{ Conditional area } & & \\
\hline & & Units & $\begin{array}{l}\text { Share in } \\
\text { total, } \%\end{array}$ & $\begin{array}{c}\text { Thousan } \\
\text { d ha }\end{array}$ & $\begin{array}{l}\text { Share in } \\
\text { total, \% }\end{array}$ & Units & \begin{tabular}{|l|}
$\begin{array}{l}\text { Share in } \\
\text { total, } \%\end{array}$ \\
\end{tabular} & \begin{tabular}{|c|}
$\begin{array}{c}\text { Thousan } \\
\text { d ha }\end{array}$ \\
\end{tabular} & $\begin{array}{l}\text { Share in } \\
\text { total, \% }\end{array}$ & Units & \begin{tabular}{|l} 
Share in \\
total, \% \\
\end{tabular} \\
\hline \multirow{2}{*}{ Obshchy Syrt } & Taskala & - & - & - & - & - & - & - & - & 1 & 20 \\
\hline & Total & - & - & - & - & - & - & - & - & 1 & 20 \\
\hline Predsyrtovy ledge & - & - & - & - & - & - & - & - & - & - & - \\
\hline \multirow{4}{*}{ Podural Plateau } & Shyngyrlau & - & - & - & - & 0.5 & 16.7 & 4.5 & 5.27 & - & - \\
\hline & Borli & - & - & - & - & - & - & - & - & 1 & 20 \\
\hline & Karatobe & - & - & - & - & 0.5 & 16.7 & 4.5 & 5.27 & - & - \\
\hline & Total & - & - & - & - & $\mathbf{1}$ & 33.4 & 9 & 10.54 & 1 & 20 \\
\hline \multirow{4}{*}{ Caspian lowland } & Zhanakala & 1 & 33 & 19 & 11.8 & - & - & - & - & - & - \\
\hline & Terekti & - & - & - & - & 1 & 33.3 & 60 & 70.26 & - & - \\
\hline & Bokey Orda & - & - & - & - & 1 & 33.3 & 16.4 & 19.2 & - & - \\
\hline & Total & 1 & 33 & 19 & 11.8 & 2 & 66.6 & 76.4 & 89.46 & - & - \\
\hline \multirow{6}{*}{$\begin{array}{l}\text { The Zhaiyk River } \\
\text { valley }\end{array}$} & Baiterek & 0.83 & 27.7 & 60.33 & 37.7 & - & - & - & - & 1.5 & 30 \\
\hline & $\begin{array}{c}\text { Territory subordinated to the } \\
\text { city of Uralsk }\end{array}$ & - & - & - & - & - & - & - & - & 0.5 & 10 \\
\hline & Terekti & 0.33 & 11 & 20.33 & 12.75 & - & - & - & - & 1 & 20 \\
\hline & Akzhaiyk & 0.5 & 16.7 & 40 & 25 & - & - & - & - & - & - \\
\hline & Borli & 0.33 & 11 & 20.33 & 12.75 & - & - & - & - & - & - \\
\hline & Total & 2 & 67 & 141 & $\mathbf{8 8 . 2}$ & - & - & - & - & 3 & 60 \\
\hline Total & & 3 & 100 & 160 & 100 & 3 & 100 & 85.4 & 100 & 5 & 100 \\
\hline
\end{tabular}

The obtained level of the recreational potential shows which of the territories identified in the region are the most promising from the point of view of the recreational development of these territories and their active inflow into the tourist and recreational complex of the region. According to the table, a map of the distribution of the level of recreational development by zones of the studied region has been drawn (Figure 3).

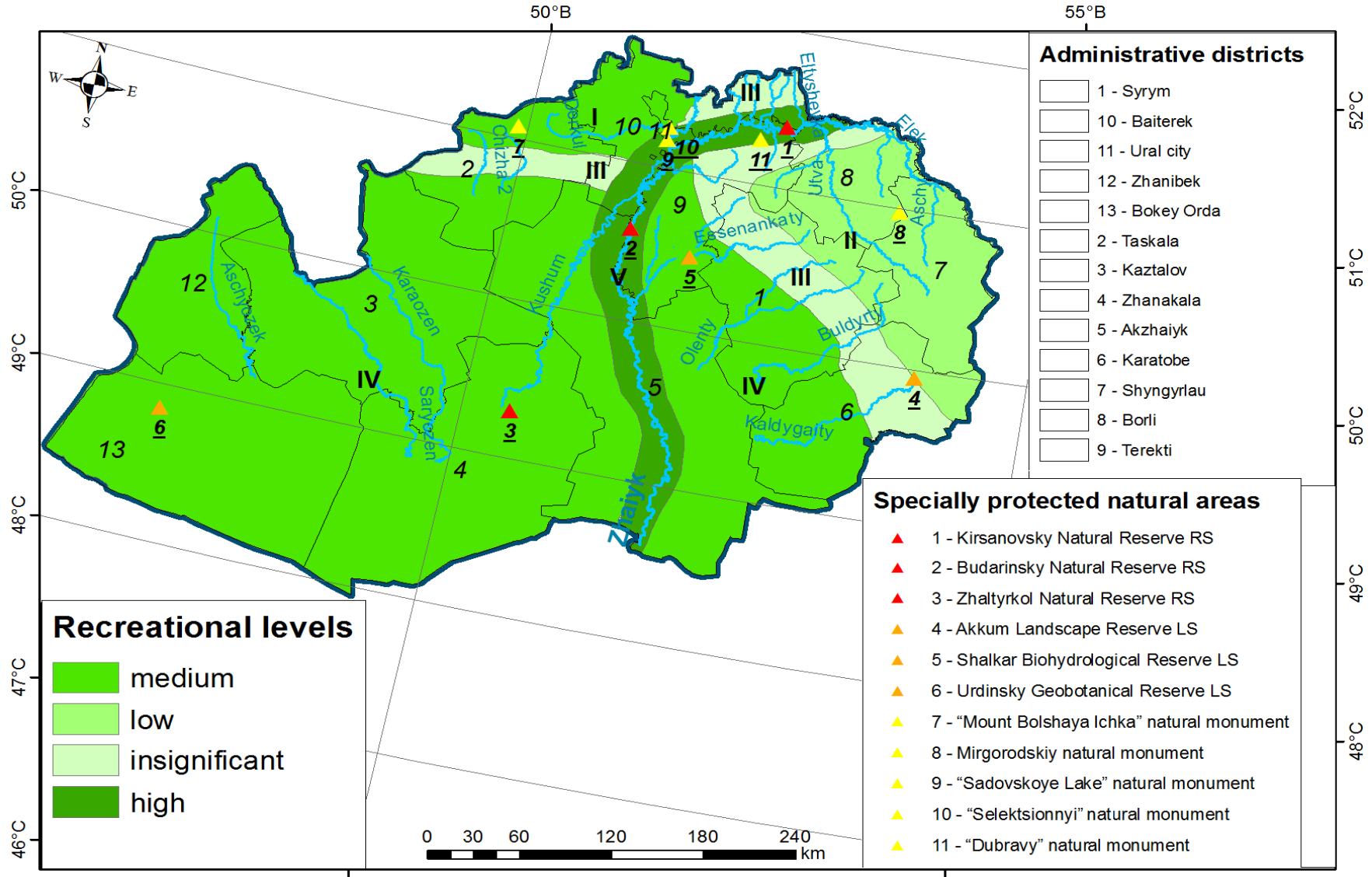

Figure 3. The level of recreational development in the recreational zones of the West Kazakhstan region 
Table 5. Assessment of the recreational potential of the West Kazakhstan region in accordance with regional differentiation

\begin{tabular}{|c|c|c|c|c|c|c|}
\hline \multirow{2}{*}{ Indicator } & \multicolumn{6}{|c|}{ Recreational zone } \\
\hline & Obshchy Syrt T & Predsyrtovy ledge & Podural Plateau & Caspian lowland & The Zhaiyk River valley & Total \\
\hline \multicolumn{7}{|c|}{ Reserves of republican significance } \\
\hline Quantity, \% & - & - & - & 33 & 67 & 100 \\
\hline Rank by quantity & - & - & - & 2 & 1 & - \\
\hline Conditional area, $\%$ & - & - & - & 11.8 & 88.2 & 100 \\
\hline Rank by area & - & - & - & 2 & 1 & - \\
\hline Cumulative rating & - & - & - & 389.4 & 5909.4 & - \\
\hline Cumulative rank 1 & - & - & - & 2 & 1 & - \\
\hline \multicolumn{7}{|c|}{ Reserves of local significance } \\
\hline Quantity, \% & - & - & 33.4 & 66.6 & - & 100 \\
\hline Rank by quantity & - & - & 2 & 1 & - & - \\
\hline Conditional area, $\%$ & - & - & 10.54 & 89.46 & - & 100 \\
\hline Rank by area & - & - & 2 & 1 & - & - \\
\hline Cumulative rating & - & - & 352 & 5958 & - & - \\
\hline Cumulative rank 2 & - & - & 2 & 1 & - & - \\
\hline \multicolumn{7}{|c|}{ Natural monuments } \\
\hline Quantity, \% & 20 & - & 20 & - & 60 & 100 \\
\hline Cumulative rank 3 & 3 & - & 2 & - & 1 & - \\
\hline $\begin{array}{l}\text { The total number of } \\
\text { points for the } 3 \\
\text { cumulative ranks }\end{array}$ & 3 & 0 & 4 & 3 & 2 & - \\
\hline $\begin{array}{l}\text { Recreational } \\
\text { potential level }\end{array}$ & Medium & Insignificant & Low & Medium & High & - \\
\hline $\begin{array}{l}\text { Recreational } \\
\text { development priority }\end{array}$ & Effective development & $\begin{array}{l}\text { Least development } \\
\text { priorities }\end{array}$ & Possible development & Effective development & $\begin{array}{l}\text { Highest development } \\
\text { priorities }\end{array}$ & - \\
\hline
\end{tabular}

\section{CONCLUSION}

As the results of assessment of the recreational potential using this method have shown, a significant part of the nature reserve fund, and therefore the natural recreational potential in this context, falls on the floodplain landscapes and ecosystems of the Zhaiyk River valley. According to the research results presented in Figure 3, the Zhaiyk River valley is characterized by a high level of recreational potential (the total number of points for three ranks is 2) and the highest development priorities. In terms of area, this recreational zone occupies $7.8 \%$ of the total area of the West Kazakhstan region. The average level of the recreational potential (3 points) is noted for the ecosystems of the Caspian lowland, which occupies large areas of the region (68.4\% of the total area) and the area of Obshchy Syrt (4.1\%). A low level of recreational potential is characterized by the territory of the Podural Plateau, which accounts for $10.7 \%$ of the region's territory. And zero indicators are noted on the territory of the Predsyrtovy ledge (9\%), which is a transitional zone of the Caspian lowland to more elevated areas.

In conclusion, it can be noted that this methodology for assessing the natural resource potential fairly objectively reflects the level of recreational potential. And although this method operates with only one assessment criterion - the presence and nature of specially protected natural areas, it can become one of the criteria for a comprehensive assessment of the tourist and recreational potential of a territory, which include many both natural and socio-economic indicators and factors for development of the tourist and recreational sector of the economy.

\section{REFERENCES}

Akhmedenov, K.M. (2020). Tourist and recreational potential of the salt lakes of Western Kazakhstan. Geojournal of Tourism and Geosites, 30(2), 782-787. https://doi.org/10.30892/gtg.302spl01-505

Akhmedenov, K., Petrishchev, V., Abisheva, S., Bauedinova, G., \& Nugmanova, M. (2015). Rodniki i lechebnye gryazi solyanokupol'nyh geosistem Zapadnogo Kazahstana [Springs and therapeutic muds of salt-domed geosystems in Western Kazakhstan]. Vestnik Kazakhskogo natsional'nogo universiteta (Bulletin of the Kazakh National University). Geographic series, 2(41), 424-429 (in Russian).

Akhmedenov, K., Petrishchev, V., Noreika, S., \& Ramazanov, S. (2017). Perspektivy sozdaniya osobo ohranyayemoi pripodnoi territorii "Gora Maloye Bogdo" [Prospects for the creation of a specially protected natural area "Mount Maloe Bogdo"]. Voprosy geografii i geoekologii (Geography and geoecology issues), 3, 3-18 (in Russian).

Amelchenko, V., Galimov, M., Ramazanov, S., Tereshchenko, T., Kabdulova, G., \& Cherevatova, T. (2006). Geographiya Zapadno-Kazahstanskoi oblasti [Geography of the West Kazakhstan region]. Uralsk, Kazakhstan, $4.28 \mathrm{Mb}$ (Electronic textbook).

Azhayev, G., Esimova, D., Sonko, S.M., Safarov, R., Shomanova, Zh. \& Sambou, A. (2020). Geoecological environmental evaluation of Pavlodar region of the Republic of Kazakhstan as a factor of perspectives for touristic activity. GeoJournal of Tourism and Geosites, 28(1), 104-113. https://doi.org/10.30892/gtg.28108-455

Beketova, A., Berdenov, Z., Mendybayev, E., Safarov, R., Shomanova, Zh. \& Herman, G.V. (2019). Geochemical monitoring of industrial center fordevelopment of recreational areas (on the example of Khromtau-Don industrial hub, Kazakhstan). GeoJournal of Tourism and Geosites, 27(4), 14491463. https://doi.org/10.30892/gtg.27428-447

Berdenov, Z.G., Atasoy, E., Mendybayev, E.H., Ataeva, G. \& Wendt, J.A. (2016). Geosystems geoecological assessment of the basin of rivers for tourist valorization. Case study of Ilek river basin. Geojournal of Tourism and Geosites, no. 2, vol. 18, p. 187-195.

Chibilev, A. (1987). Reka Ural (Istriko-geographicheskiye I ecologicheskie ocherki o basseine reki Ural) [The Ural River (Historical, Geographical and Ecological Essays on the Ural River Basin)]. Leningrad Gidrometeoizdat, Russia.

Chibilev, A. (2008). Bassein Urala: istoriya, geographiya, ecologiya [The Urals basin: history, geography, ecology]. Yekaterinburg SV-96, Russia.

Darbayeva, T., Ramazanova, N., Chashina, B., Berdenov, Zh., Mendybayev, E., Wendt, J.A. \& Atasoy, E. (2020). Modeling soil erosion in the Chagan river of the west Kazakhstan with using Rusle and GIS tools. J.Environ. Biol., 41, 396-404. http://doi.org/10.22438/jeb/41/2(SI)/JEB-18

Deac, L.A., Gozner, M. \& Sambou, A. (2019). Ethnographic museums in the rural areas of Crișana Region, Romania - Keepers of local heritage, tradition and lifestyle. GeoJournal of Tourism and Geosites, 27(4), 1251-1260. https://doi.org/10.30892/gtg.27411-430

Doskach, A.A. (1954). Geomorphologicheskie issledovaniya v Prikaspiiskoi nizmennosti [Geomorphological studies in the Caspian lowland]. Moscow, Publishing house of the Academy of Sciences of the USSR, Russia.

Erdavletov, S. (2000). Geographiya turizma: istoriya, teoriya, metody, praktika [Geography of tourism: history, theory, methods, practice]. Almaty, Kazakhstan.

Ilieș, A., Hurley, P.D., Ilieș, D.C., \& Baias, S. (2017). Tourist animation -a chance adding value to traditional heritage: case studys in the Land of Maramures (Romania). Revista de Etnografie si Folclor, New Series 1-2, Issue: 1-2, Pages: 131-151. 
Ilieș, A., \& Grama, V. (2010), The external western balkan border of the European Union and its borderland: premises for building functional transborder territorial systems. in Annales-Anali za Istrske in Mediteranske Studije-Series Historia et Sociologia, Volume: 20, Issue: 2, pp. $457-468$.

Ilieș, D.C., Caciora, T., Herman, G.V., Ilieș, A., Ropa, M., \& Baias, Ș. (2020). Geohazards affecting cultural Heritage Monuments. a complex case study from Romania. GeoJournal of Tourism and Geosites, 31(3), 1103-1112. https://doi.org/10.30892/gtg.31323-546

Ilieș, D.C., Buhas, R., Ilieș, M., Ilieș, A., Gaceu, O., Pop, A.C., Marcu, F., Buhas, S.D., Gozner, M., \& Baias, S. (2018). Sport Activities and Leisure in Nature 2000 Protected Area - Red Valley, Romania. Journal of Environmental Protection and Ecology, 19, No 1, 367-372.

Lincu, A., Ilieş, M., Ilieş, D.C., Herman, G.V., Baias, S., Gozner, M., Costea, M., \& Mihincău, D. (2018). Conservating the traditional cellars of Salacea, Bihor County, Romania. GeoJournal of Tourism and Geosites, 23(3), 748-758, https://doi.org/10.30892/gtg.23311-325.

Kabiyev, Y.S., Berdenov, Z.G., Dzhanaleeva, K.M., Atasoy, E. \& Wendt, J.A. (2018). Landscape ecological analysis of the modern delta of the Ural (Zhayik) river. Geojournal of Tourism and Geosites, no. 3, vol. 23, p. 644-655.

Kuskov, A., Golubeva, V., \& Odintsova, T. (2005). Rekreatsionnaya gepgraphiya [Recreational geography]. Moscow, MPSI, Flinta, Russia.

Mironenko, N., \& Tverdokhlebov, I. (1981). Rekreatsionnaya gepgraphiya [Recreational geography]. Publishing house of Moscow University, Russia.

Mitchell, L.S. (1979). The geography of tourism: An introduction. Annals of Tourism Research, 6 (3), 235-244. https://doi.org/10.1016/0160-7383(79)90100-2

Nuruly, E., \& Aktymbaeva, A. (2017). Prikladnye aspekty razvitiya agroturizma v Zapadno-Kazahstanskoi oblasti Respubliki Kazahstan [Applied aspects of the development of agritourism in the West Kazakhstan region of the Republic of Kazakhstan]. Nauchnyy rezul'tat. Tekhnologii biznesa i servisa. (Scientific result. Business and service technologies). 3 (3), 41-52. https://doi.org/10.18413/2408-9346-2017-3-3-40-51

Page, S. (2011). Tourism management. Oxon: Routledge Advances in Tourism, England.

Petrenko, A., Dzhubanov, A., Fartushina, M., Chernyshev, D., \& Tubetov, Zh. (2001). Zelenaya kniga Zapadno-Kazahstanskoi oblasti [Green Book of the West Kazakhstan region]. Uralsk: Publishing house RIO ZKGU, Kazakhstan.

Ramazanov, S. (2009). Formirovanie ekologicheskogo karkasa Zapadno-Kazahstanskoi oblasti [Formation of the ecological framework of the West Kazakhstan region]. Problems of regional ecology, 2, 152-158.

Ramazanov, S. (1998). Pripoda, naseleniye i hozyaistvo Zapadno-Kazahstanskoi oblasti [Nature, population and economy of the West Kazakhstan region]. Uralsk, Kazakhstan.

Ramazanov, S. (2003). Uzly ecologicheskogo karkasa Zapadno-Kazahstanskoi oblasti i ih rol' v sohranenii biologicheskogo i landshaftnogo raznoobraziya [The nodes of the ecological frame of the West Kazakhstan region and their role in the preservation of biological and landscape diversity]. Ecological problems of protected territories in Russia. Togliatti, Russia.

Ramazanova, N., Berdenov, Z.H., Ramazanov, S., Kazangapova, N., Romanova, S., Toksanbaeva, S., \& Wendt, J. (2019). Landscape-geochemical analysis of steppe zone basin Zhaiyk. News of the National Academy of Sciences of the Republic of Kazakhstan, 4, 33-41.

Ramazanova, N., \& Dzhanaleyeva, G. (2012). Problems of Integrated Assessment of Geo-ecosystems of Steppe Zone of Ural River Basin. Journal of Environmental Science and Engineering. 1(8), 1037-1043.

Svanbayeva, Z., Sagatbayev, E., \& Salikhov, T. (2016). Potentsial I perspektivy razvitiya turizma na territorii proektiruyemogo gosudarstvennogo prirodnogo rezervata "Bokeyorda" Zapadno-Kazahstanskoi oblasti ]Potential and prospects of tourism development on the territory of the projected state natural reserve "Bokeyorda" of the West Kazakhstan region] Novosti nauki Kazakhstana. (Science News of Kazakhstan), 2 (128).

Suleimenov, I., Egemberdieva, Z., Bakirov, A., Baipakbayeva, S., Kopishev, E., \& Mun, G. (2020). Efficiency Problem of renewable energetics systems in the context of a «smart house» concept. E3S Web of Conferences, Volume 164, 5 May 2020.

Wendt, J.A. (2020). Outline of geotourism and geoparks development in Europe. 96 International Scientific Conference "Global Challenges -Scientific Solutions II", 96-101.

Yegorova, E., \& Motrich, O. (2010). Metodika otsenki prirodnogo turistsko-rekreatsionnogo potentsiala regiona [Methodology for assessing the natural tourist and recreational potential of the region]. Regional'naya ekonomika: teoriya i praktika. (Regional economy: theory and practice), 43 (178).

*** Phizicheskaya geographiay Kazahstana [Physical geography of Kazakhstan] / edited by Vilesov, E., Naumenko, A., Veselova, L., Aubekerov, B. (2009). Almaty: Kazakh University, Kazakhstan

***Resolution of the Government of the Republic of Kazakhstan, dated September 26, 2017 No. 593 "On approval of the list of specially protected natural areas of republican significance" [Electronic resource: https://zakon.uchet.kz/rus/docs/P1700000593 (date of appeal 26.10.2020].

***Specially protected areas of West Kazakhstan region [Electronic resource: http://ibirzha.kz/osobye-territorii/ (date of appeal 26.10.2020]

*** Teoreticheskiye osnovy rekreatsionnoi geographii [Theoretical foundations of recreational geography] / edited by Preobrazhensky, V. (1975). Moscow, Russia.

*** Tourism, Mobility and Second Homes / Edited by Michael, H.C. \& Müller, D.K. (2004). Clevedon - Buffalo - Toronto. 